\title{
【討 議】
}

\section{高田至郎著 “埋設管路一地盤系の復元力特性と地震応答解析” への討議}

（土木学会論文報告集第 249 号・1976 年 5 月掲載）

討議者（Discussion）

鵜 飼 恵 三 (新渴大学) By Keizo Ugai

本論文は，埋設管の軸方向の動的復元力特性に関する 実験結果をまとめたものであり，いくつかの興味ある結 果が述べられ，それなりに意義のあるものと思われる. しかしながら，実験結果をまとめる際の考え方に問題が あり，また論文中にいくつかの誤まりがあると思われる ので，以下に筆者の意見を述べたい。

（1）本論文に限らず，軸方向のすべりを考虑した地 中埋設管の動的挙動に関する過去の多くの研究では, す べりの条件を管と地盤との間の相対変位により規定して いる。このような方法は厳密な考察を進める上で支障に なるばかりでなく, 埋設管の地震応答解析に適用した場 合に誤った結果を生じるであろう，なぜなら，本来すべ りが生じるか否かは，管の外周上に生じる軸方向のせん 断応力が管と地盤との間の摩擦抵抗を越えるか否かによ って規定するのがより合理的なはずだからである．この ことをさらに詳細に説明するために, 以下に筆者の考え を簡単にまとめてみる．正弦 $S$ 波が管軸方向に対し角 度 $\phi$ をなして入射する場合を例にとり議論を進める.

管外周上に作用する管軸方向のせん断応力を $\tau_{r z}$ で 表わし，軸方向のすべりが生じる条件を次式で規定す る.

$$
\tau_{r z}>\tau_{0}
$$

ここで， $\tau_{0}$ は管外壁 と地盤との間の最大すべり抵抗 応力である． $\tau_{r z}$ は，一般に管の同一断面の外周上にお いても一定ではないが， $L / a(L: S$ 波の波長, $a:$ 管の 外半径)が非常に大きい場合にはほぼ一定となる.したが って, 実用上はその外周上での平均值 $\tau_{a}$ によって近似 することができ，式（21）の代わりに次式を用いうる.

$$
\tau_{a}=\frac{1}{2 \pi} \int_{0}^{2 \pi} \tau_{r z} d \theta>\tau_{0}
$$

すべりが生じる以前の管一地盤系の挙動は弾性的であ るとすれば文献 13) の式 (2-13) 〜式 (2-15) より

$$
\tau_{a}=-K_{a}\left(U_{a}-\sin \phi \cdot u_{g}\right) / 2 \pi a
$$

ここで, $K_{a}$ は動的地盤反力系数であり, 管径, $S$ 波 の入射角 $\phi$ ・波長 $L$,地盤の ゚゚アソン比・せん断弾性係
数の関数である. 全無限弾性地盤を仮定する場合には, $K_{a}$ は文献 13) の式 (2-16) で表わせる. $U_{a}, u_{g}$ はお のおの管の応答変位振幅, $S$ 波の変位振幅である. 式 (23) の右辺の中で $\left(U_{a}-\sin \phi \cdot u_{g}\right)$ (文献 13) では座標 軸の方向の相違により $U_{a}+\sin \phi \cdot u_{g}$ となっているが， わかりやすいように $U_{a}-\sin \phi \cdot u_{g}$ と表わした）は管と 地盤との間の軸方向の相対変位を表わす.

式 (22), (23) より，すべりが生じる際の相対変位振 幅 $U_{R}$ は次式で表わせる.

$$
U_{R}=U_{a}-\sin \phi \cdot u_{g}=-2 \pi a \tau_{0} / K_{a}
$$

式 (24) は，相対変位が， $a$ および $K_{a}$ ，したがって， 管径, 波長および地盤の諸定数の関数であることを示し ている. 特に, $U_{R}$ が波長によって変化する点は重要で あり, 相対変位にもとづいてすべりの条件を規定し, こ れを埋設管の震動計算に適用するという方法が不適切で あることを示していると考えられる。

次に，管軸方向の振動方程式より次式が成立する（た だし，管の慣性力は無視する).

$$
\tau_{a}=E A k^{2} \cos ^{2} \phi U_{a} / 2 \pi a
$$

ここで, $E, A$ 管のヤング率, 断面積であり, $k$ は 波数 $(=2 \pi / L)$ である.いま, $L / a$ がきわめて大きく, 管は地盤と同一の挙動をするものとすれば,

$$
U_{a}=u_{g} \sin \phi
$$

が成り立つ. また, 管厚 $t$ は管径に比してかなり小さい ものとすれば, 式 (25), (26) より次式が成り立つ.

$$
\tau_{a}=E t k^{2} \cos ^{2} \phi u_{g} \sin \phi
$$

さらに，管の軸ひずみを $\varepsilon_{A}$, 軸応力を $\sigma_{A}$ と書くと

$$
\left.\begin{array}{rl}
\sigma_{A} & =E \varepsilon_{A} \\
& =E k \cos \phi \cdot U_{a} \\
& =E k \cos \phi \cdot u_{g} \sin \phi
\end{array}\right\}
$$

が成り立つ ${ }^{13)}$

式 (27) は，管厚が大きいほど $\tau_{a}$ が大，つまりす心゙ りが生じやすいことを示し, 逆に, 波長が大きいほど $\tau_{a}$ は小，つまりすべりが生じにくいことを示している.一 般に，管は管径が大きいほど管厚も大となるようにつく 
られているであろらから，管径が大きいほどすべりが生 じやすいと言えるであろう.

式（27）は軸応力が管のヤング率に比例し，波長に反 比例することを示す．特に， $\sigma_{A}$ が管径と無関係である ことに注意し, 式 (26) に関して述べたことと合わせて 考えると，一般に管径が小さい場合には，すべりが生じ る以前に管に非常に大きな軸応力が生じる可能性がある と考えられる.つまり，管厚が小さい(よって管径が小 さい) ほどすべりが生じにくいといらことは弾性領域内 にとどまりやすいことを意味し，すべることによって軸 応力を緩和する機会が，管厚の大きい(よって管径が大 きい）管に比べて少なくなるため, 地震時に被害を生じ る可能性が大きくなることを意味する.このことは, 久 保・片山らの述べる震害例 ${ }^{14)}$ をうまく説明するのではな いかと考えている.

これらの結論は, すべりの条件を式 (21) もしくは (22)によって規定することにより比較的簡単に導くこ とができたが，相対変位を用いたこれまでの方法によっ ては導くことのできないものである.
(2) 著者は論文中の式 (8)

$$
A E \frac{\partial^{2} u}{\partial x^{2}}-k^{\prime}{ }_{s}(U-u)^{\alpha}=0
$$

を管軸方向の静的な運動のつり合い式として定めている が, 復元力 $k_{s}{ }^{\prime}(U-u)^{\alpha}$ は論文中の Fig. 15 の ヒステ リシスループの最大点を連ねたものであり, これを運動 のつり合い式を満たす復元力と考えるには相当の無理が あると思われる．種々のヒステリシスループを描く場合 の計算結果と比較をするなどして, この復元力の仮定が 近似的に正しいか否かを検討することが必要であろう。

(3) 式 (11) から（12）は導けないのではないか.

式（12）を微分しても式（11）にならない.

\section{参考文献}

13）鵜飼恵三・若林正彦・松野操平: 斜方向上り入射する 平面せン断波汶対する地中埋設管の動的応答特性, 第 14 回地震工学研究発表会, pp. 181 184, 1976-7.

14） 久保慶三郎・片山恒雄・佐藤暢彦 : 地中埋設管震害の定 量的解析, 筑 4 回日本地震工学シンポジウム, pp. 655 $662,1975-11$.
著者の論文を詳細に読まれ、ご討議頂き,また著者の 意見を述べる機会を与えられたことに謝意を表します。

討議の第 1 の問題点は, 埋設管が地震時に滑りを生じ るか否かの規範となる条件を何によって与えるかといら 点にあると思われます. 討議者は弾性波動論より計算し た平均的なせん断応力が, ある最大滑り抵抗応力ょりも 大きくなった場合に滑りが生じるとし, せん断応力が,

管径・波長・地盤諸定数などの関数となっていることか ら，相対変位のみで滑りの条件を与えることに問題があ ることを指摘していると考えられます. 討議者による波 動論の計算結果を用いれば, 応答としての相対変位も上 記諸量の関数となることは明らかであり, もし, 滑りの 条件を相対変位で与えるとしても同様の議論が展開され ることを第 1 に指摘しておきたいと考えます.

著者が本論文中で行った実験は, 静止した地盤中に埋 設された特定の管径をもつ管路に強制的に変位を与え て, 管周辺に働く摩擦力の合力を測定しており, その結 果より管変位の増加割合に対して摩擦力の増加割合が急 激に小さくなる点での変位を滑り出しの変位と定義して います.したがって, 管路が地震外力を受けて, 滑りの 応答特性を示すか否かの条件を相対変位で与えることと は意味が異なっています.すなおち, 本実験は摩擦復元 力の特性を求めようとしたものであり, 滑りの条件関 しては,これらの結果をもととして別途検討する必要が

\section{あります。}

なお, 討議者が検討されているような応力または力で 滑りの条件を与える方法については, すでに著者らが文 献 1) で解析・計算を行っており, 以下簡単にその考え 方を述べてみたいと思います.

地震時に埋設管の横断面内半径方向に作用する平均的 な土圧 $P$ は次式で推定される.

$$
P=\left(1+K_{0}\right) \rho_{s} g H / 2 \text {. }
$$

ここに, $K_{0}, \rho_{s} g, H$ はそれぞれ震度を考慮した土圧係 数, 地盤の単位体積重量, 地表面より管の中心までの哚 さである.さらに，地盤と管の間の動的摩擦係数を $f_{0}$ とすれば, 管路の長手方向 $l$ 区間に働く摩擦力 $F_{0}$ は 次式となる.

$$
F_{0}=f_{0} P l
$$

一方, 著者らが弾性波動論を用いて, 管路一地盤系の 相互作用を解析し, 管路が綐振動を行う場合の軸力 $F$ を演算した結果次式が得られる。

$$
\frac{F}{\rho_{s} \pi a^{2} \omega^{2} u_{g}}=\frac{f^{*}}{\left(c_{0} / c\right)^{2}-1+\left(\rho_{s} / \rho_{p}\right) f^{*} /\left\{1-(b / a)^{2}\right\}}
$$

ここに, $u_{g}, \omega, c$ は管路軸方向に伝播する地震波動の変 位振幅, 振動数, 波速である. また, $\rho_{p} g, c_{0}$ 管体の 単位体積重量, 管体内での 縦波速度である. さらに, $v_{l}, v_{t}$ を地盤内縦波および横波速度, $H_{n}{ }^{(1)}(z)$ を $n$ 次 
のハンケル関数とすれば， $f^{*}$ は次式で与えられる.

$$
\begin{aligned}
& f^{*}=\frac{-2}{Q\left(h^{*} a\right) /\left\{\left(c / v_{l}\right)^{2}-1\right\}+Q\left(g^{*} a\right)} \\
& Q(z)=z \frac{H_{0}^{(1)}(z)}{H_{1}^{(1)}(z)} \\
& h^{*} a=(a \omega / c) \sqrt{\left(c / v_{l}\right)^{2}-1} \\
& g^{*} a=(a \omega / c) \sqrt{\left(c / v_{t}\right)^{2}-1}
\end{aligned}
$$

式 (3) の軸力 $F$ が式 (2) で与えられる 摩擦抵抗力 $F_{0}$ よりも大きければ滑りを生じると考えられる. そし

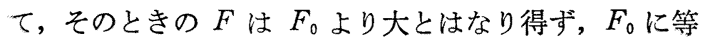
しいと見なすのが妥当であろう。

すなわち, 応答計算に用いる軸力を $F_{x}$ とすれば, 次 式で滑り出しの条件を規定することができる.

$$
\left.\begin{array}{l}
\left|F_{x}\right|<F_{0} ; F_{x}=F, \\
\left|F_{x}\right| \geqq F_{0} ; F_{x}= \pm F_{0}
\end{array}\right\}
$$

滑りが生じる場合の軸力 $F_{0}$ は管路と地盤の相対速度の 符号によってその方向が変化するので, 式 (5) のよう に正負の両符号をもっている. これより, 相対変位に関 する管の縦振動運動方程式は次式となる.

$$
\begin{aligned}
A_{p} \rho_{p} g \frac{\partial^{2} u}{\partial t^{2}} & -A_{p} E \frac{\partial^{2} u}{\partial x^{2}}=-A_{p} \rho_{p} g \frac{\partial^{2} u_{g}}{\partial t^{2}} \\
& +F_{x} \ldots \ldots \ldots \ldots \ldots \ldots \ldots \ldots \ldots \ldots \ldots \ldots \ldots \ldots \ldots \ldots \ldots \ldots
\end{aligned}
$$

ここに, $A_{p}, E$ は管の断面積およびヤング率である.式 (6)を用いれば, 滑りをも含んだ管路の応答計算が可能 となる.

なお, 討議の文中, 式 (21) で与えられている $\tau_{0}$ は, 本文の式 (2) の形で推定するのも一方法であろう.ま た, 本文の式 (3) で与えられる軸力は, 入力地震動の 特性, 管および周辺地盤の物理諸定数の関数となってい ることはいうまでもなく，式（3）を用いて，それぞれ が与える影響を評価できる. 式 (6) 以降の計算方法お よび具体的計算結果は文献 1) を参照されたい.

第 2 の討議点は, ヒステリシスループを描く復元力特 性を, その最大点曲線で置換することの妥当性の有無で あります. 著者の論文中の式 (8) には, 慣性力項, 減 衰力項がともに含まれておらず, 式 (8) は縦来, 線形 ばねを用いて静的に算定されている相対変位を, 同じく
静的に，滑りの特性をもつ非線形ばねを用いて計算した ものであり，上記両者の差異を検討しようとしたもので あります. したがって, 討議者の指摘されている減衰力 はもちろんのこと, 慣性力の影響をも別途に検討して, 式（8）の妥当性を調べる必要があります．著者らは, 管路一地盤系の多質点系モデルを用いて, 滑り特性を示 すばねを等価線形系に置換して 確率論な 取り扱いによ り, 応答值に与える慣性力, 減衰力, 復元力の影響を検 討しています2). 用いる計算パラメーターによりかなり の違いはありますが, 文献 2) で対象とした系では, 概 して慣性力の影響はほとんど無視できる程度であり, 減 衰力は数\%程度といえそうです. 詳細な検討は続行中で あり, 今後発表の機会をもてるものと思っております.

第 3 の討議点に関しては, 著者の論文中の式 (11) を 積分して, 式 (12) を誘導する際に, 次に示すような近 似を行っており, 式 (12) の微分によって, 直接に式 (11) を誘導することはできません. すなわち, 式 (11) の積分過程で,

$$
\begin{array}{r}
\int \frac{d u^{*}}{d x} \frac{d}{d x}\left(\frac{V}{c_{a}}\right) d x=\int \varepsilon_{A} * \frac{d}{d x}\left(\frac{V}{c_{a}}\right) d x \\
\approx \varepsilon_{A} * \int \frac{d}{d x}\left(\frac{V}{c_{a}}\right) d x \ldots \ldots \ldots \ldots \ldots . . .
\end{array}
$$

の近似を行っています.ここに, $\varepsilon_{A^{*}}=\left(d u^{*} / d x\right)_{\max }$ で あります.

本来, $x$ の関数であるべき $d u^{*} / d x$ が上式の積分中 では, 定数 $\varepsilon_{A}^{*}$ として取り扱われています. というの は, 式 (13) 以降の展開からも知られるように, 本文で は, 軸ひずみの最大振幅について検討がなされており, 式 (12) では， $\varepsilon_{A}$ * に関する 2 次式を誘導することに目 標がおかれています.

\section{参考 文 献}

1）高田至郎・小浜文朗 : 地震時における 管路の滑りに関す る一考察, 昭和 51 年度土木学会関西支部年次 学 術 講演 会, pp. I-18-1 2, 昭 51.5 .

2）元山峰夫・高田至郎 : 地中構造物の地震応答に関する確 率論的評価, 第 31 回土木学会年次学術講演会, 第 1 部, p. 376 , 昭 51.10 . 